\title{
Roles of the circulating renin-angiotensin-aldosterone system in human pregnancy
}

\author{
Eugenie R. Lumbers and Kirsty G. Pringle \\ School of Biomedical Sciences and Pharmacy and Mothers and Babies Research Centre, Hunter Medical Research Institute, \\ University of Newcastle, Newcastle, New South Wales, Australia
}

Submitted 24 January 2013; accepted in final form 2 October 2013

\begin{abstract}
Lumbers ER, Pringle KG. The roles of the circulating renin-angiotensin-aldosterone system in human pregnancy. Am J Physiol Regul Integr Comp Physiol 306: R91-R101, 2014. First published October 2, 2013; doi:10.1152/ajpregu.00034.2013.-This review describes the changes that occur in circulating renin-angiotensin-aldosterone system (RAAS) components in human pregnancy. These changes depend on endocrine secretions from the ovary and possibly the placenta and decidua. Not only do these hormonal secretions directly contribute to the increase in RAAS levels, they also cause physiological changes within the cardiovascular system and the kidney, which, in turn, induce reflex release of renal renin. High levels of ANG II play a critical role in maintaining circulating blood volume, blood pressure, and uteroplacental blood flow through interactions with the ANG II type I receptor and through increased production of downstream peptides acting on a changing ANG receptor phenotype. The increase in ANG II early in gestation is driven by estrogen-induced increments in angiotensinogen (AGT) levels, so there cannot be negative feedback leading to reduced ANG II production. AGT can exist in various forms in terms of redox state or complexed with other proteins as polymers; these affect the ability of renin to cleave ANG I from AGT. Thus, during pregnancy the rate of ANG I production varies not only because levels of renin change in response to homeostatic demand but also because AGT changes not only in concentration but in form. Activation of the circulating and intrarenal RAASs is essential for normal pregnancy outcome subserving the increased demand for salt and, hence, water during pregnancy. Thus, the complex integration of the secretions and actions of the circulating maternal renin-angiotensin system in pregnancy plays a key role in pregnancy outcome.
\end{abstract}

renin-angiotensin-aldosterone system; pregnancy; fluid and electrolyte balance; renal function; circulation

IN HUMAN PREGNANCY, THE MATERNAL and fetal circulating reninangiotensin-aldosterone systems (RAAS) and various tissue renin-angiotensin systems (RAS) interact to ensure a satisfactory pregnancy outcome. Tissue RASs critically involved in normal pregnancy are the ovarian, intrauterine (placental and decidual), and the intrarenal RASs. The nonrenal RASs not only play key roles in ovulation, implantation, placentation, and development of the uteroplacental and umbilicoplacental circulations, but they also contribute to the activity of the circulating maternal RAAS, so influencing maternal cardiovascular and renal function. The role of the maternal circulating RAAS is the topic of this review. It should be appreciated that the fetus also has a circulating functional renin-angiotensin system, and this system together with its intrarenal RAS is essential for normal renal development and function $(33,81)$.

The activity of the maternal circulating RAAS in pregnancy does not solely depend on release of active renin from the kidney. Although this source of renin is important, increased production of angiotensinogen by the liver is also a major influence. Its activity is also influenced at various stages of

Address for reprint requests and other correspondence: Emeritus Scientia Professor Eugenie R. Lumbers, School of Biomedical Sciences, Univ. of Newcastle, Callaghan, Newcastle, NSW Australia, 2308 (e-mail: Eugenie. Lumbers@newcastle.edu.au). gestation by contributions from the ovary and uteroplacental unit. The actions of the maternal circulating RAAS are mediated through various ANG peptides and receptors (see Fig. 1). ANG II acting via the ANG II type 1 receptor $\left(\mathrm{AT}_{1} \mathrm{R}\right)$ is predominantly vasoconstrictor; it is also a major regulator of aldosterone secretion. There are additional actions of ANG II mediated via an angiotensin type 2 receptor $\left(\mathrm{AT}_{2} \mathrm{R}\right)$ and of other ANG peptides, in particular, ANG 1-7 via the Mas receptor and ANG IV via $\mathrm{AT}_{4} \mathrm{R}$. ANG IV can, however, also act via $\mathrm{AT} 1_{\mathrm{a}} \mathrm{R}$ in the mouse kidney (88). These other ANG peptides, which are also part of the circulating RAAS, and their actions are also likely to contribute to pregnancy outcome.

This review describes our current understanding of the circulating RAAS, how it changes during normal pregnancy, and how it contributes to changes in cardiovascular and renal function to maintain fluid and electrolyte balance and tissue perfusion.

\section{Circulating RAAS}

The circulating RAAS is defined by the action of renin, a 36-kDa aspartyl protease, which cleaves a Val-Leu bond in a large 62-kDa $\alpha 2$-globulin substrate, angiotensinogen (AGT), to form ANG I. ANG I is converted to ANG II by angiotensinconverting enzyme (ACE). ANG II is the major ANG peptide; 
A

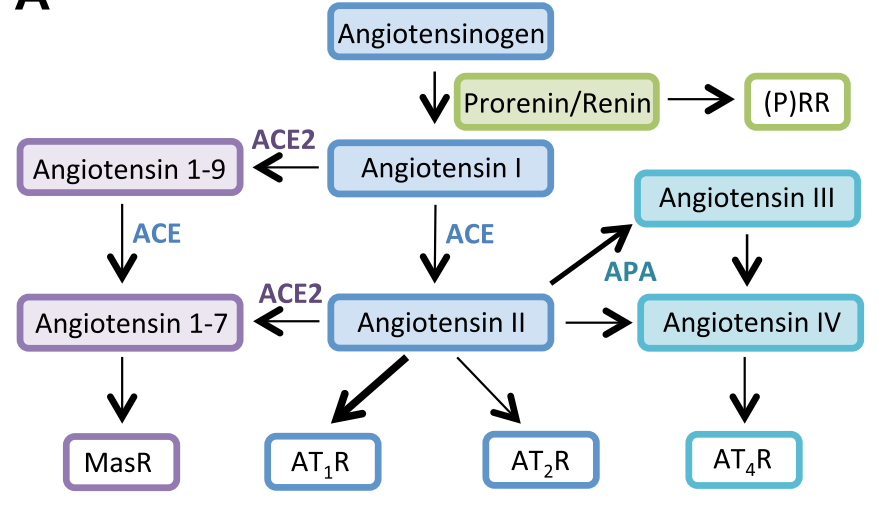

B

NH2-Asp-Arg-Val-Tyr-Ile-His-Pro-Phe-His-Leu-Val-Ile-His-Thr-Glu-COOH

NH2-Asp-Arg-Val-Tyr-Ile-His-Pro-Phe-His-Leu-COOH

ACE

NH2-Asp-Arg-Val-Tyr-Ile-His-Pro-Phe-COOH

Aminopeptidase A

NH2-Arg-Val-Tyr-Ile-His-Pro-Phe- $\mathrm{COOH}$

Aminopeptidase $B$

$\mathrm{NH} 2-$ Val-Tyr-Ile-His-Pro-Phe-COOH carboxypeptidase

ANG IV

NH2-Asp-Arg-Val-Tyr-Ile-His-Pro-COOH

ANG (1-7)

Fig. 1. A: renin-angiotensin system. (P)RR, prorenin receptor; ACE, angiotensin-converting enzyme; ACE2, a homolog of angiotensin-converting enzyme; APA, aminopeptidase A. $\mathrm{AT}_{2} \mathrm{R}$ and $\mathrm{AT}_{1} \mathrm{R}$ are $\mathrm{ANG}$ II receptors; $\mathrm{AT}_{4} \mathrm{R}$ or IRAP is a receptor for ANG IV and MasR a receptor for ANG (1-7). $B$ : angiotensin peptides. ANG (1-7) can be produced by ACE2 actions on ANG II or ANG I.

its most well-described biological actions are mediated via the $\mathrm{AT}_{1} \mathrm{R}$, (Fig. 1A). Other ANG peptides in the circulation include ANG (1-7), which is formed at the fastest rate from ANG II $(15,64)$, ANG III, and ANG IV (Fig. 1B) $(3,15)$.

ANG II, as well as acting via its $\mathrm{AT}_{1} \mathrm{R}$, can also bind to the type 2 receptor, $\mathrm{AT}_{2} \mathrm{R}$. Many actions of the $\mathrm{ANG}$ II/ $/ \mathrm{AT}_{2} \mathrm{R}$ interaction oppose the actions of $\mathrm{ANG}$ II/AT ${ }_{1}$ R. Briefly, ANG $\mathrm{II} / \mathrm{AT}_{1} \mathrm{R}$ interactions cause vasoconstriction, aldosterone synthesis, secretion, angiogenesis, and cell proliferation. Those

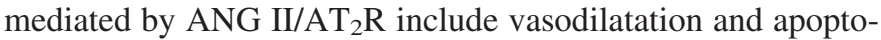
sis (15). ANG (1-7) acts via the MasR, a G protein-coupled receptor (64), and many of its actions oppose the ANG II/ $\mathrm{AT}_{1} \mathrm{R}$-induced effects, as do the actions of ANG IV mediated via the $\mathrm{AT}_{4} \mathrm{R}$, also known as IRAP [insulin regulated aminopeptidase (3)]. ANG IV/IRAP-induced effects include hypertrophy, vascularization, inflammation, and vasodilation (10), as well as actions mediated via $\mathrm{AT}_{1} \mathrm{Rs}$ (88). IRAP has been shown to be identical to placental oxytocinase (45).

The discovery of a precursor of active renin (now called prorenin) many years ago (32) was initially regarded as of little biological significance because prorenin, which has a 28 -amino acid prosequence that covers its catalytic site, was thought to be biologically inactive. It could be shown to be activated in vitro by low pH (32), cold, and proteases such as trypsin (44) and cathepsin D (43). Even today, the biological significance of "in vivo" proteolytic activation of prorenin, remains obscure except for the specific proteolysis that occurs within the juxtaglomerular cells lining the afferent arterioles of the kidney that results in storage and release of active renin from these cells into the blood.

In 2002, the biological significance of prorenin was realized following the discovery of a prorenin receptor, $(\mathrm{P}) \mathrm{RR}$. The 45-kDa protein cloned by Nguyen et al. (49) is, in part, identical to a 8.9-kDa truncated protein "M8-9" that is copurified with a vacuolar proton-ATPase, or V-ATPase. (P)RR binds prorenin so that its catalytic site is exposed and ANG I can be cleaved from AGT (49). There are three pathways via which prorenin bound to (P)RR can have biological effects: first by cleavage of ANG I from AGT, second by activation of intracellular signaling [phosphorylation of ERK1/ERK2 or by activation $\mathrm{p} 27 / \mathrm{HSP}$ pathway $(49,66)]$ and third, through the interaction of $(\mathrm{P}) \mathrm{RR}$ with Wnt signaling pathways (48). The fact that $(\mathrm{P}) \mathrm{RR}$ knockouts are embryo-lethal indicates that (P)RR plays an essential role in normal development.

A soluble form of $(\mathrm{P}) \mathrm{RR}, \mathrm{s}(\mathrm{P}) \mathrm{RR}$, has also been described. It is the $28-\mathrm{kDa}$ portion of the receptor that is cleaved from the M8-9 component by the enzyme furin (48) and is found in the circulation. Thus, circulating prorenin, which is much more abundant in the blood than active renin and which increases to very high levels early in pregnancy (Fig. $2 A$ ), is no longer confined to the role of an inactive precursor of active renin. It has its own biological activity, possibly as a circulating hormone. $\mathrm{s}(\mathrm{P}) \mathrm{RR}$ may also be important in influencing the rate of formation of ANG I from AGT in plasma and other bodily fluids (89).

\section{Changes in Components of the Circulating RAAS in Normal Pregnancy}

Angiotensinogen. As stated above, the activity of the circulating renin-angiotensin system depends upon both the amount of renin capable of interacting with AGT and the amount of AGT. Plasma renin activity is a measure of the angiotensinforming capacity of plasma. AGT production parallels that of estrogen; the correlation coefficient for AGT and estradiol-17 $\beta$ is 0.60 and for AGT and estriol, it is 0.68 (25). Thus, both AGT (Fig. $2 B$ ) and ANG II levels rise progressively throughout pregnancy (4). The significance of the increase in AGT in human pregnancy (70) has been underestimated despite the claim by Skinner in 1993 that "at all stages of pregnancy, angiotensinogen is the most important factor determining plasma renin activity and presumably ANG II production" (69).

Native AGT is a $62-\mathrm{kDa}$ protein, although it can exist in high-molecular-weight forms (see below). It is a serpin with the cleavage site for renin (a Val-Leu bond) in a relatively inaccessible site. Accessibility by renin to this site is improved by a redox-induced conformational change. Oxidation of the Cys 18-Cys 138 bond in AGT (89) significantly increases its renin binding affinity in the presence of the (P)RR. Oxidized AGT reacting with renin has a $K_{\mathrm{m}}$ that is about $30 \%$ of reduced AGT, while in the presence of the (P)RR, oxidized AGT has a $K_{\mathrm{m}}$ only $9 \%$ that of reduced AGT. That is, oxidized AGT has 

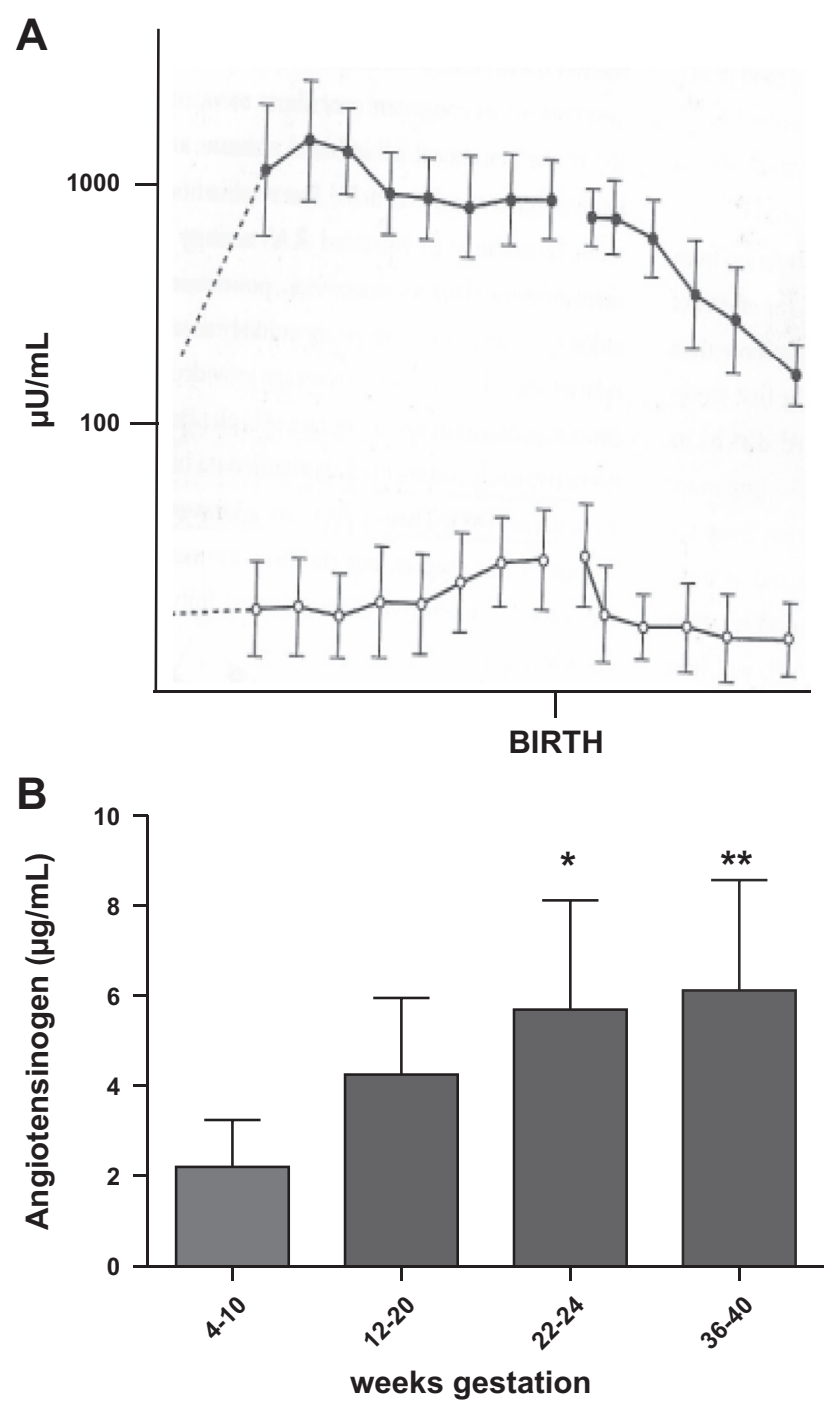

Fig. 2. A: plasma prorenin $(\bullet)$ and active renin $(O)$ levels throughout pregnancy [redrawn with permisson from the Endocrine Society from the Journal of Clinical Endocrinology, Derkx FH, Alberda AT, de Jonng FH, Zeilmaker FH, Makovitz JW, and Schalekamp MA, vol. 65, 1987, permission conveyed through Copyright Clearance Center; from Derkx et al. (16)]. B: angiotensinogen levels $(\mu \mathrm{g} / \mathrm{ml})$ in maternal plasma throughout pregnancy. Levels were measured by incubation of maternal plasma with an excess of human renal renin. Angiotensinogen levels in early pregnancy were less than those measured after 20 wk gestation, $* P<0.035$ and ${ }^{*} * P<0.001$ compared with values obtained in first $10 \mathrm{wk}$ gestation. [Drawn from raw data presented by Skinner et al. (70)].

a higher affinity for renin than reduced AGT, and the presence of the (P)RR further enhances AGT's affinity for renin caused by oxidation of AGT. (P)RR has no effect, however, on the $K_{\mathrm{m}}$ of the reduced AGT-renin reaction $\left[K_{\mathrm{m}}\right.$ is $86 \%$ of that measured in the absence of (P)RR]. Therefore, with increasing levels of AGT in pregnancy, and the fact that the oxidized-toreduced ratio of AGT has been shown to be increased in preeclampsia (89), the role of AGT has, as Skinner pointed out, been underestimated, in terms of its ability to affect ANG II production. Clearly, the roles of oxidized AGT and (P)RR in the etiology of abnormal pregnancy outcomes, such as preeclampsia, intrauterine growth restriction, and preterm birth deserve detailed investigation. Other conformational changes in the molecular structure of AGT may also alter the kinetics of the renin-AGT reaction. For example, the Met 235 polymorphism in the AGT gene is associated with a conformational change that leads to an increased rate of formation of ANG II (89).

The molecular weight of circulating AGT can vary because it forms polymers. Monomeric AGT is a protein of $61.5 \mathrm{kDa}$ or $65.5 \mathrm{kDa}$ (depending on glycosylation) produced by the liver (80). Polymeric forms of AGT alter the rate of the renin-AGT reaction.

High-molecular-weight AGTs, which are different from those in plasma from nonpregnant women, have been found in plasma from pregnant women. Levels of high-molecularweight AGT rise throughout pregnancy and are about $16 \%$ of total AGT; they increase further in pregnancy-induced hypertension and hypertension that is exacerbated in pregnancy (79). The reaction of high-molecular-weight AGT with renin is slow (86).

High-molecular-weight AGTs were first described by Gordon and Sachin (20) and quantified by Tewksbury and Dart (79). Five distinct forms exist in extra fetal tissues, i.e., amnion, chorion, and placenta, while only three forms exist in plasma (78). In plasma from pregnant women, high-molecularweight AGTs are polymers complexed with other proteins, such as the proform of eosinophil major basic protein (proMBP), which is highly expressed in the placenta. Low levels of proMBP occur in Down's syndrome and are also associated with poor pregnancy outcome (86). It is produced by the trophoblast placental X cells (extravillous trophoblast) (54). 2:2 polymers of proMBP/AGT and 2:2:2 of proMBP/AGT/Cd3g occur in plasma from pregnant women (55). $\mathrm{Cd} 3 \mathrm{~g}$ is complement. ProMBP and $\mathrm{Cd} 3 \mathrm{~g}$ complexes with AGT only occur in plasma from pregnant women, although there are high-molecular-weight forms of AGT (140 and 100 $\mathrm{kDa}$ ), which account for about $3-5 \%$ of total AGT in plasma from nonpregnant subjects (46).

Therefore, not only are levels of plasma AGT increased in pregnancy, but AGT also influences the rate of production of ANG II, depending on its redox state and the amount complexed with other proteins.

Prorenin and active renin. In the luteal phase of the menstrual cycle, prorenin levels peak shortly after ovulation, while active renin levels rise in the mid-luteal phase (68). This suggests that ovarian prorenin is secreted at ovulation. The ovarian follicle contains renin, $99 \%$ of which is in the form of prorenin, although ANG I and ANG II are also both present, suggesting that either prorenin is nonproteolytically activated by binding to $(\mathrm{P}) \mathrm{RR}$ or the very small amount of active renin, perhaps formed spontaneously, is sufficient to generate ANG I and ANG II (34).

Maternal plasma prorenin levels are at a maximum at 8-12 wk gestation $(16,70)$, being about 10 times nonpregnant levels at their peak (16), while active renin levels do not rise until $\sim 20$ wk of pregnancy (Fig. $2 A$ ).

A strong correlation between serum renin levels (total) and the number of ovarian follicles was found in women in whom cycling was managed by LH, FSH, and human chorionic gonadotrophin (hCG) (27). Ovarian prorenin is a major contributor to circulating prorenin levels in early pregnancy. Derkx et al. (16) demonstrated that in a woman with primary ovarian failure in whom embryo transfer was performed, plasma prorenin levels were only about $17 \%$ of those normally 
seen in early pregnancy while levels of active renin, which are secreted only by the kidney, were similar to those found in normal pregnant women. The contribution of the uteroplacental unit to the maternal circulating prorenin levels has not been demonstrated as convincingly.

Very high levels of prorenin might contribute to an increase in active renin levels, perhaps after $20 \mathrm{wk}$ gestation when the materno-placental interface is fully established. This could occur through spontaneous conversion to active renin, as it is thought that there is an equilibrium between the two molecules (67). Alternatively, prorenin could interact with the $28-\mathrm{kDa}$ soluble prorenin receptor, thus increasing the biological activity of the circulating RAAS through two actions, exposure of the renin catalytic site, as well as affecting the rate of reaction of renin with AGT.

It is surprising that despite the increased demand for retention of salt and water to compensate for the very significant increase in cardiovascular volume that occurs in pregnancy (so that it is effectively "underfilled") and the salt-losing effects of changes in renal function (discussed below), there is not a marked increase in active renin until later in pregnancy. This emphasizes the critical role of AGT in regulating plasma ANG II levels early in gestation. This tightly controlled activity of the RAAS through the action of estrogens on AGT provides a "fail-safe" mechanism that offsets the natriuretic effects of the high glomerular filtration rate (GFR) and high levels of progesterone, both of which are characteristic of normal pregnancy $(1,51)$. The "locking" of AGT synthesis to estrogen production means that its regulation is freed from the control by complex integratory pathways and/or maternal behavior, e.g., salt intake.

Since active renin is only secreted by the kidney, one has to conclude that the influence of AGT on plasma ANG II levels results in a negative feedback suppression to midluteal levels of active renin in early gestation, and only after $20 \mathrm{wk}$ do those mechanisms that normally balance renin activity to homeostatic demand (i.e., renal sympathetic nerve activity, renal perfusion pressure, and tubular flow dynamics) become significantly more influential in the control of maternal plasma renin levels.

$A C E$. In normal pregnancy ACE activity does not change throughout gestation (56). This may not be the case in pathological pregnancies. Although we have not found any changes in ACE levels at $15 \mathrm{wk}$ gestation in women who go on to develop preeclampsia or gestational hypertension (76), pregnant diabetic rats have higher serum ACE and lung ACE than nondiabetic control animals; as well, ANG II levels are higher (84).

ACE2. ACE2 has $40 \%$ homology with ACE. It removes a single amino acid from either ANG II to form ANG (1-7) or from ANG I to form ANG (1-9), which can subsequently be cleaved to ANG (1-7) by ACE. ACE2 is primarily localized to endothelial cells. It is upregulated in disease states such as myocardial infarction and may be shed into plasma (31). ACE2 is expressed in high amounts in early gestational placentae on the syncytiotrophoblast (59); levels of expression are lower at term. In this location, placental ACE2 may cleave maternal circulating ANG II to form ANG (1-7), a vasodilator peptide, which acts via the Mas receptor (see below). As far as we can tell, ACE2 has not been measured in human plasma from pregnant women. This is because it is difficult to measure. Its catalytic activity in human plasma is inhibited. The inhibitor is a small-molecular-weight molecule; it is not a protein, nor is it a divalent cation. Removal of the inhibitor by anion-exchange, yielded plasma ACE2 activity of $4.44 \pm 0.56 \mathrm{pmol} \cdot \mathrm{ml}^{-1}$. $\mathrm{min}^{-1}$ in plasma from nonpregnant women (31). Be that as it may, the perfusion of maternal blood through the placenta and exposure to ACE2 in syncytiotrophoblast may reflect an important physiological site of production of ANG (1-7).

ANG peptides. ANG I (the decapeptide) has no known biological activity. ANG II, the octapeptide, is the most potent of the ANG peptides (Fig. $1 B$ ) having 2 receptors, ANG II type $1\left(\mathrm{AT}_{1} \mathrm{R}\right)$ and type 2 receptors $\left(\mathrm{AT}_{2} \mathrm{R}\right)$. Additional $\mathrm{ANG}$ peptides resulting from the removal of $\mathrm{N}$-terminal amino acids also exist in the circulation. Because biological activity depends on the phenyalanine grouping at the carboxy end, the heptapeptide, ANG III (des-aspartyl ${ }^{1}$-ANG II) is almost as potent as ANG II. As well, ANG III appears to be the preferred agonist for the $\mathrm{AT}_{2} \mathrm{R}$ in certain organs (e.g., the kidney), where its actions via the tubular $\mathrm{AT}_{2} \mathrm{R}$, release cGMP and cause a profound natriuresis (30). The hexapeptide, ANG 3-8, (also known as ANG IV) and pentapeptide, ANG 4-8, have a similar efficacy but are weak agonists of the $\mathrm{AT}_{1} \mathrm{R}$ because of their poor affinity (15). ANG IV, however, does have a specific receptor, IRAP, identified by Albiston et al. (3) that is involved in cognition and memory. ANG (1-7), formed by the action of a carboxypeptidase, such as ACE2 acting on ANG II (Fig. 1A) or from ANG I via other pathways acts on a very different receptor, the MasR (64).

Of these peptides, ANG II and ANG (1-7) have been most studied in human pregnancy. At 15 wk gestation, ANG II levels are lower and the ANG (1-7)/ANG II ratio higher in women carrying male fetuses than in women carrying female fetuses (75). Baker et al. (4) found that plasma ANG II levels were elevated by the second trimester. By late gestation, ANG I levels were $176.4 \pm 57.1 \mathrm{fmol} / \mathrm{ml}$ compared with nonpregnant levels of $32.4 \pm 5.6 \mathrm{fmol} / \mathrm{ml}$, and ANG II levels were about $50 \%$ above nonpregnant levels while ANG (1-7) levels were increased by about 34\% [Fig. 3 (5)]. As explained above, these high levels of ANG II and ANG (1-7) are predominantly due, at least in early gestation, to the rising levels of AGT. Since ACE2 activity has not been clearly determined in normal human plasma, it is possible that the rise in ANG (1-7) represents conversion from ANG II by ACE2 at the placental

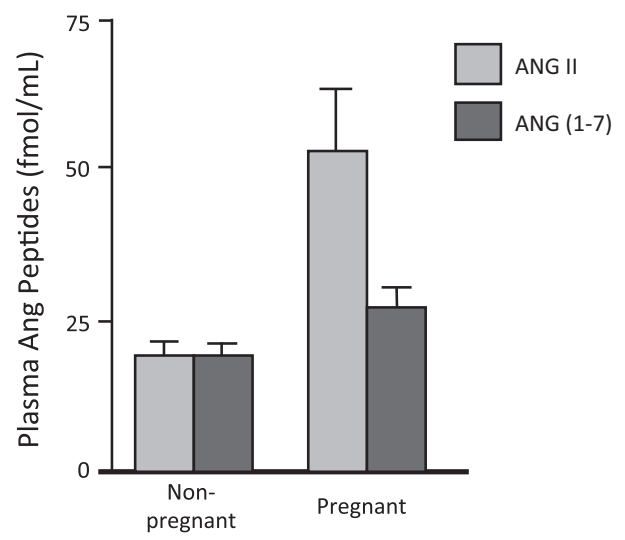

Fig. 3. ANG II and ANG (1-7) levels in plasma from nonpregnant (NP) and pregnant women in the third trimester. Data are reported as means $\pm \mathrm{SE}$ values. [Redrawn from Brosnihan et al. (5)]. 
interface $(82,83)$, but it is also possible that increased conversion of ANG II to ANG (1-7) occurs in the pregnant kidney. In Sprague-Dawley rats, Joyner et al. (28) showed that renal levels of both ACE2 and ANG 1-7 were increased in the middle to late stages of pregnancy. Coupled with the higher renal blood flow of pregnancy, it is probable that renal ACE2 makes a significant contribution to circulating levels of ANG (1-7) in human pregnancy (28).

\section{Angiotensin Receptors}

The roles of the circulating RAAS in human pregnancy cannot be considered in isolation from changes in the density of ANG receptors located in all those sites at which ANG peptides have biological actions. The ANG II receptors $\left(\mathrm{AT}_{1} \mathrm{R}\right.$, $\mathrm{AT}_{2} \mathrm{R}$ ) are $\mathrm{G}$ protein-coupled receptors (15).

$A T_{1} R$. ANG II/AT $\mathrm{AT}_{1} \mathrm{R}$ interactions acting via phospholipase $\mathrm{C}$ increase cytosolic calcium, inhibit adenyl cyclase, and activate tyrosine kinases, causing vasoconstriction, aldosterone synthesis and secretion, and cardiac hypertrophy. Significantly, ANG II acts within the central nervous system to stimulate thirst (39), vasopressin secretion (38), and sympathetic nerve activity (60), as well as inhibit cardiac vagal efferent nerve traffic (36). These actions potentiate its peripheral vasoconstrictor actions on vascular smooth muscle, thus leading to increased arterial pressure. Through actions in the zona glomerulosa of the adrenal cortex, ANG II/AT ${ }_{1} \mathrm{R}$ stimulates aldosterone synthesis and secretion (72). Within the kidney, ANG II/AT $\mathrm{A}_{1} \mathrm{R}$ interactions stimulate tubular sodium reabsorption (13). As well, ANG II acting via $\mathrm{AT}_{1} \mathrm{R}$ partially mimics the actions of growth factors using Ras pathways to activate MAPK; this action is enhanced by ANG II transactivation of growth factor signaling. Transactivation of EGF by ANG II stimulates MAPK and calcium-dependent phosphorylation leading to activation of growth factor proto-oncogenes (15).

$\mathrm{AT}_{1} \mathrm{R}$ density in vascular smooth muscle taken from pregnant rats is suppressed by $1 \mu \mathrm{M}$ of estradiol (15). The changes in $\mathrm{AT}_{1} \mathrm{R}$ density in the maternal vasculature in pregnancy are unknown, but ANG II binding to platelet $\mathrm{AT}_{1}$ Rs from pregnant women has been described. Baker et al. (4) found that platelet ANG II receptors were low throughout pregnancy, rising at 6 wk postpartum. Pawlak and MacDonald (57) showed that in nonpregnant subjects there was a negative relationship between ANG II levels and ANG II receptors. In early pregnancy this relationship was lost because at this time, there was a "significant reduction or nil receptor capacity but only a slight elevation in mean plasma angiotensin II concentration" and "this phenomenon of reduced or absent binding persisted into the third trimester when plasma angiotensin II was significantly elevated compared with all other groups" (57).

It is well known that vascular reactivity to ANG II is decreased both in terms of a reduction in pressor responses to ANG II (19) and a reduction in the reactivity of the maternal peripheral vasculature (35). Whether this is due to the counteracting effects of other vasodilator influences in pregnancy or to a reduction in $\mathrm{AT}_{1} \mathrm{R}$ is unknown, but the fact that hand vascular reactivity of pregnant women to another vasoconstrictor, namely noradrenaline, was not altered, but the response to ANG II was reduced (35), suggests that there is a reduction in $\mathrm{AT}_{1} \mathrm{R}$ vascular receptor density, as found by others in platelets $(4,57)$.
$A T_{2} R$. ANG II acting via the $\mathrm{AT}_{2} \mathrm{R}$ receptor causes vasodilation and apoptosis. In pregnancy, myometrial $\mathrm{AT}_{2} \mathrm{R}$ are downregulated, but in the uterine arteries of pregnant sheep, a different picture is seen. Vascular $\mathrm{AT}_{2} \mathrm{R}$ are upregulated by estrogens (62).

In uterine arteries from pregnant sheep, there are $\mathrm{AT}_{2} \mathrm{R}$, but these are not present in uterine arteries from nonpregnant sheep $(7,41)$. Because ANG II/AT $2 \mathrm{R}$ interactions mediate vasodilation via nitric oxide (NO) and bradykinin, the presence of $\mathrm{AT}_{2} \mathrm{R}$ in the uterine arteries could be important in offsetting the vasoconstrictor action of ANG II, so maintaining a high uteroplacental blood flow. This proposition would seem to be supported by the finding in sheep that uteroplacental flow did not change during short-term intravenous infusions of ANG II of $<60 \mathrm{ng} \cdot \mathrm{kg}^{-1} \cdot \mathrm{min}^{-1}$ (46) or 4-h infusions of $20-30$ $\mathrm{ng} \cdot \mathrm{kg}^{-1} \cdot \mathrm{min}^{-1}$ (74). However, when $20-30 \mathrm{ng} \cdot \mathrm{kg}^{-1} \cdot \mathrm{min}^{-1}$ intravenous infusions of ANG II were continued for 16-24 h, uteroplacental flow did decrease, and the fetuses became hypoxemic (74). Infusions $\left(30 \mathrm{ng} \cdot \mathrm{kg}^{-1} \cdot \mathrm{min}^{-1}\right.$ ) of ANG II for 24 $\mathrm{h}$ cause uterine arteries from pregnant sheep (studied in vitro) to contract more vigorously in response to ANG II. This is due, in part, to downregulation of $\mathrm{AT}_{2} \mathrm{R}$. Thus $\mathrm{AT}_{2} \mathrm{R}$ in the pregnant uterine vasculature protects against the vasoconstrictor actions of ANG II unless high circulating levels of ANG II are sustained over many hours, resulting in their downregulation (40). In addition, in female rats, low doses of ANG II cause a fall in blood pressure (BP) not seen in male rats (63). In genetically modified mice, $\mathrm{AT}_{2} \mathrm{R}$-null mice develop high blood pressure in the third trimester (77), and $\mathrm{AT}_{2} \mathrm{R}$ receptor antagonism abolishes the midgestation decline in $\mathrm{BP}^{\text {in }} \mathrm{AT}_{1 \mathrm{a}}{ }^{-1-}$ and $\mathrm{C} 57 \mathrm{BL} / 6 \mathrm{~J}$ mice (73). Thus, $\mathrm{AT}_{2} \mathrm{R}$ plays a role in regulation of maternal blood pressure and uteroplacental flow in animal models, and it is likely that $\mathrm{AT}_{2} \mathrm{Rs}$ are upregulated in the systemic, as well as the uteroplacental vasculature of the pregnant human.

MasR. In 2003, Santos et al. (65) showed that ANG (1-7) acted via a $G$ protein orphan receptor, Mas. ANG (1-7) acting via this pathway is also a vasodilator via endothelium-dependent mechanisms, in particular, via NO. ANG (1-7) is also antiaquaretic and promotes thirst $(29,37)$, important actions of the RAAS regulation of fluid and electrolyte homeostasis in pregnancy.

Insulin-regulated aminopeptidase. IRAP, also known as the $\mathrm{AT}_{4}$ receptor, is the receptor for ANG IV (3). It is the same as placental oxytocinase (45). ANG IV bound to IRAP inhibits it (2). Estrogen treatment of ovariectomized ewes results in downregulation of IRAP in the outer myometrial layer (45). Whether or not the inhibitory effect of ANG IV on IRAP plays a role in parturition is unknown at this time.

\section{Role(s) of the Circulating RAAS in Pregnancy}

Underfilled hypotensive cardiovascular system of pregnancy. The RAAS is activated in the 2 nd half of the menstrual cycle, following ovulation. At this time, mean arterial pressure falls (from $81.7 \pm 0.2$ during the follicular phase to $75.4 \pm 0.2$ $\mathrm{mmHg}$ in the proliferative phase), and systemic vascular resistance is decreased (declines from 1,224 \pm 82 to $959 \pm 59$ dynes $\cdot \mathrm{s}^{-1} \cdot \mathrm{cm}^{-5}$, Fig. $4 A$ ). These changes in cardiovascular function could stimulate renin release via the renal baroreceptor or increased renal sympathetic nerve activity. 

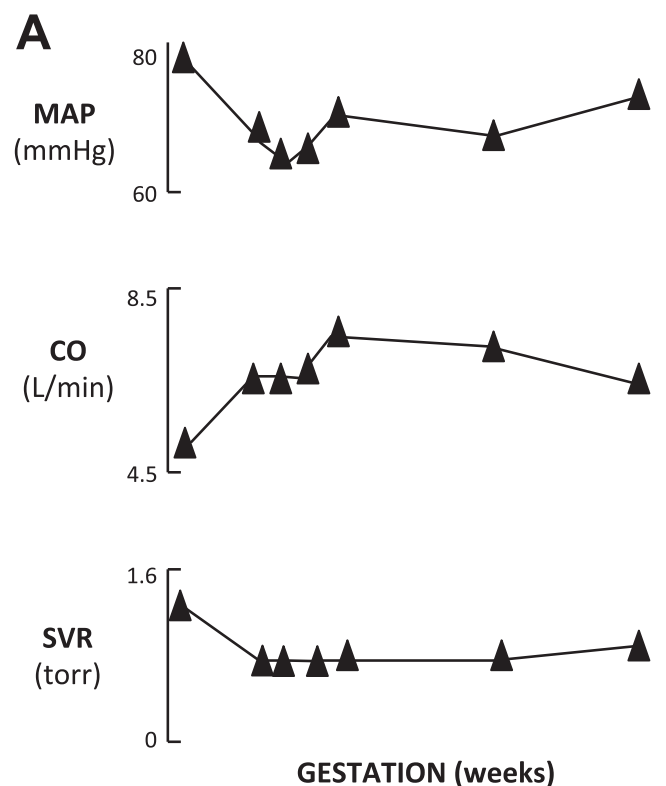

B
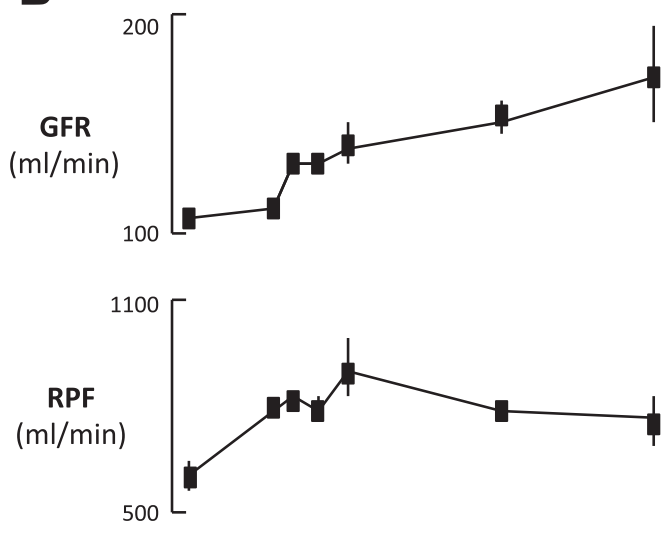

GESTATION (weeks)

Fig. 4. Changes in mean arterial pressure (MAP, $\mathrm{mmHg}$ ), cardiac output $(\mathrm{CO}$, $1 / \mathrm{min}$ ), and systemic vascular resistance (SVR, torr; $A$ ); as well as glomerular filtration rate (GFR, $\mathrm{ml} / \mathrm{min}$ ) and renal plasma flow (RPF, $\mathrm{ml} / \mathrm{min})(B)$ in pregnancy. Measurements were made in nonpregnant women and throughout pregnancy up to $36 \mathrm{wk}$. [Redrawn from Chapman et al. (8) with correction to $x$-axes; Macmillan Publishers Ltd., Kidney International, 54, 2056-2063, 1998].

Also, glomerular filtration rate is increased from $109 \pm 6$ to $116 \pm 7 \mathrm{ml} \cdot \mathrm{min}^{-1} \cdot 1.73 \mathrm{~m}^{2}$ [Fig. $4 B(9)$ ] and progesterone levels increase from $0.22 \pm 0.02$ to $8.13 \pm 1.55 \mathrm{ng} / \mathrm{ml}$. The rise in renin activity $\left(0.36 \pm 0.05\right.$ to $\left.1.21 \pm 0.18 \mathrm{ng} \cdot \mathrm{ml}^{-1} \cdot \mathrm{h}^{-1}\right)$ and aldosterone levels [from $3.1 \pm 0.3$ to $8.5 \pm 1.0 \mathrm{ng} / \mathrm{ml}(9)$, Fig. 5] should be seen as a compensatory response to the changes in GFR, the increased capacity of the cardiovascular compartment and to the salt-losing effects of progesterone (9).

Thus, late in the menstrual cycle, the circulating RAAS is activated, because the fall in maternal blood pressure acting via the renal baroreceptor and sympathetic nervous system, the salt-losing effects of a high GFR stimulating the macula densa and inhibition of aldosterone by progesterone, all stimulate release of renin from the kidney (in particular, active renin). No further increase in active renin levels then occurs until $20 \mathrm{wk}$ gestation. The progressive rise in renin activity and ANG II prior to this time (i.e., $20 \mathrm{wk}$ ) is the result of estrogen-induced stimulation of AGT production (see above). The integrated pattern of changes leading to the observed alterations in the circulating RAAS in pregnancy is summarized schematically in Figs. 6 and 7.

Maternal cardiovascular and renal function are profoundly altered by the presence of a conceptus. There is marked vasodilation and an increase in blood flow, particularly to the uterus, breasts, skin, and kidneys, presumably in response to metabolic demand and to eliminate the waste products of metabolism. There must also be an increase in coronary blood flow to cope with the increase in cardiac output. An increase in vascular compliance occurs very early in pregnancy and threatens maintenance of blood pressure, even though cardiac output is increased. The increased capacitance of the maternal circulation is due to both a reduction in systemic vascular resistance and an increase in global arterial compliance.

What causes this increase in capacitance of the maternal circulation? The following may be involved: angiogenesis and vascular remodeling; relaxin; vasodilator peptides of the RAS [e.g., ANG (1-7)]; downregulation of the $\mathrm{AT}_{1} \mathrm{R}$ and upregulation of $\mathrm{AT}_{2} \mathrm{R}$; vascular endothelial growth factor (VEGF); and NO, kallikrein-kinin, and prostanoids.

This topic has been reviewed by Valdes et al. (83). The role of the RAS in creating the proangiogenic state of pregnancy is discussed below. Evidence for downregulation of $\mathrm{AT}_{1} \mathrm{R}$ in pregnancy has been cited above as has the vasodilator roles of ANG II or ANG III/AT ${ }_{2} \mathrm{R}$ interactions, ANG IV, and ANG (1-7). These all also involve other dilator systems (e.g., NO, kallikrein-kinin system, and prostacyclin) but of particular interest is the role of relaxin.

As stated above, cardiac output rises in the first trimester, mainly due to an increase in stroke volume, but systemic
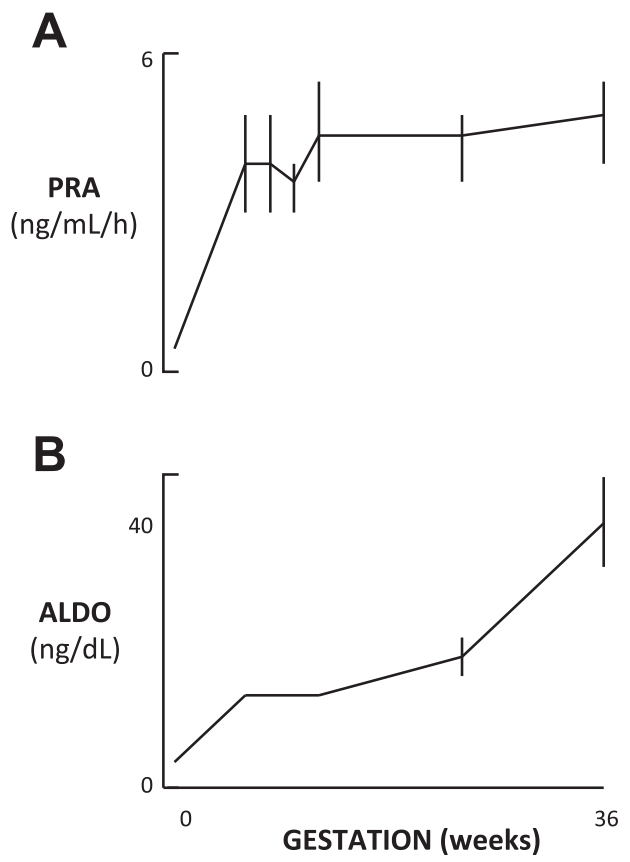

Fig. 5. Changes in plasma renin activity $\left(\mathrm{PRA} ; \mathrm{ng} \cdot \mathrm{ml}^{-1} \cdot \mathrm{h}^{-1}\right)(A)$ and plasma aldosterone levels (ALDO; ng/dl) $(B)$ in human pregnancy. [Redrawn from Chapman et al. (8); Macmillan Publishers Ltd., Kidney International, 54, 2056-2063, 1998]. 


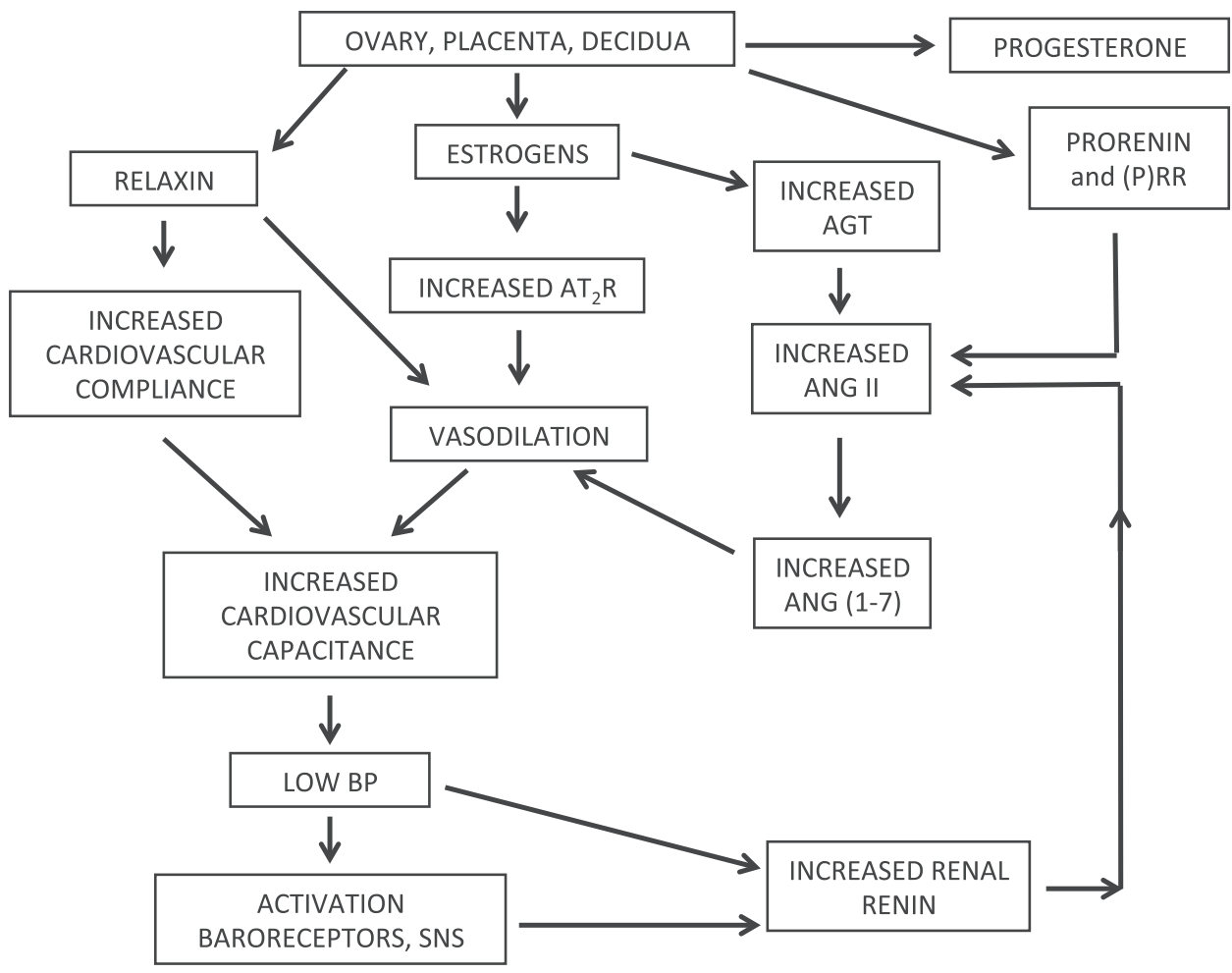

Fig. 6. The actions of ovarian, placental, and possibly decidual hormones directly and indirectly via their effects on maternal physiology on the circulating maternal renin-angiotensin system in human pregnancy.

vascular resistance (SVR) falls to a greater extent, so that by the beginning of the second trimester arterial pressure is reduced, effective renal plasma flow has increased by about $80 \%$, and GFR is $50 \%$ above nonpregnant values (Fig. 4) (1). At the beginning of the second trimester, the decrease in systemic vascular load reaches its nadir and the increase in global arterial compliance (AC) peaks. This synergism has been proposed by Conrad to depend on the actions of the ovarian hormone, relaxin (Figs. 6 and 7) (11). Animal studies have shown that relaxin plays a major role in pregnancy as a vasodilator, in osmoregulation, and renal vasodilation $(11,12$, 50). Relaxin-induced increases in renal blood flow might be thought to account for pregnancy-induced increases in GFR, and this seems to be the case in rodents (14). However, in nonpregnant human volunteers recombinant human relaxin caused a rise in renal blood flow, but this was not accompanied by an increase in GFR; thus the situation in human pregnancy seems to be more complex (71).

Conrad and Novak (12) postulates that not only is relaxin a vasodilator, but acting via a relaxin receptor induces matrix

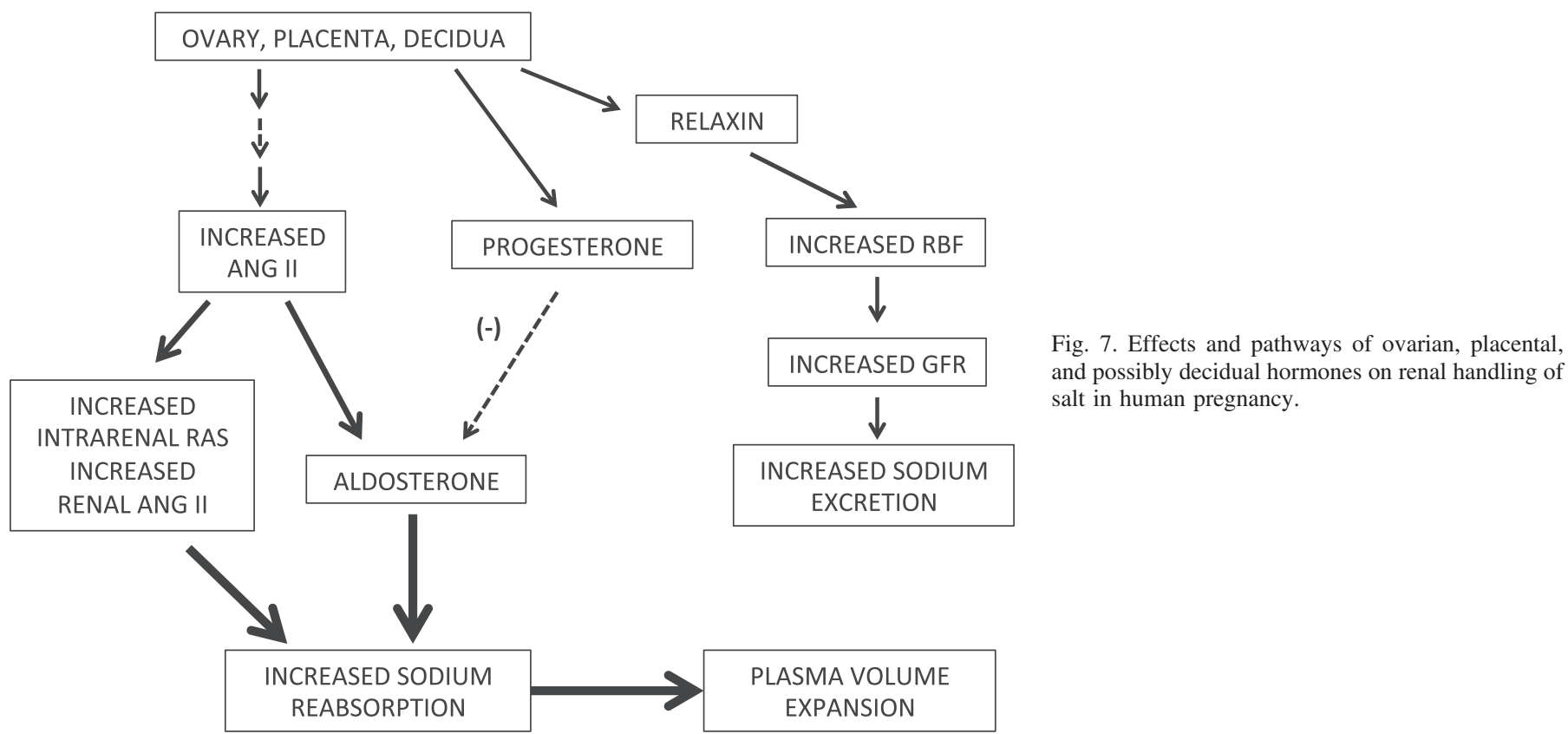


metalloproteinase-2 (MMP2), which has the ability to cleave endothelin ${ }_{1-32}\left(\mathrm{ET}_{1-32}\right)$ from big endothelin. $\mathrm{ET}_{1-32}$ acting via $\mathrm{ET}_{\mathrm{B}}$ in endothelial cell caveolae induces nitric oxide synthase and so increases NO and vascular relaxation. This adds to the fall in renal vascular resistance and systemic vascular resistance. Also, MMP-2, a gelatinase, affects the vascular extracellular matrix of small vessels leading to increases in global arterial compliance (which is derived from the cardiac output and the diastolic decay of the aortic waveform) $(11,12)$. This increase in global AC prevents excessive falls in diastolic pressure resulting from the decrease in SVR, decreases the loss of pulsatile work by the heart, and contributes to the underfilling of the vascular system, which together with the reduction in SVR, results in a massive demand for salt and water to fill the cardiovascular system in the face of a high GFR, causing salt and water loss. The RAAS plays a pivotal role in maintaining $\mathrm{BP}$ and retaining salt and water under these circumstances, possibly aided by increased renal sympathetic nerve activity, and early in pregnancy, a lack of a rise in plasma atrial natriuretic peptide levels (Fig. 8) (8), which do not increase until $12 \mathrm{wk}$ gestation, although, thereafter, they are increased relative to the nonpregnant state $(26,61)$.

Hunger for salt to maintain pregnancy and renal function. No other physiological state is characterized by such an intense activation of the renin-angiotensin-aldosterone system as occurs in human pregnancy (Figs. 6 and 7). A pregnant woman requires about $500 \mathrm{mEq}$ of sodium in normal pregnancy, about $20 \mathrm{mmol} / \mathrm{wk}$ (21). Adequate levels of sodium are required to maintain the extracellular volume, which includes an expanded circulating blood volume and the demands of the conceptus for salt and water. For changes in these values during pregnancy, see Ref. 1. The RAAS is the mechanism that fulfills this
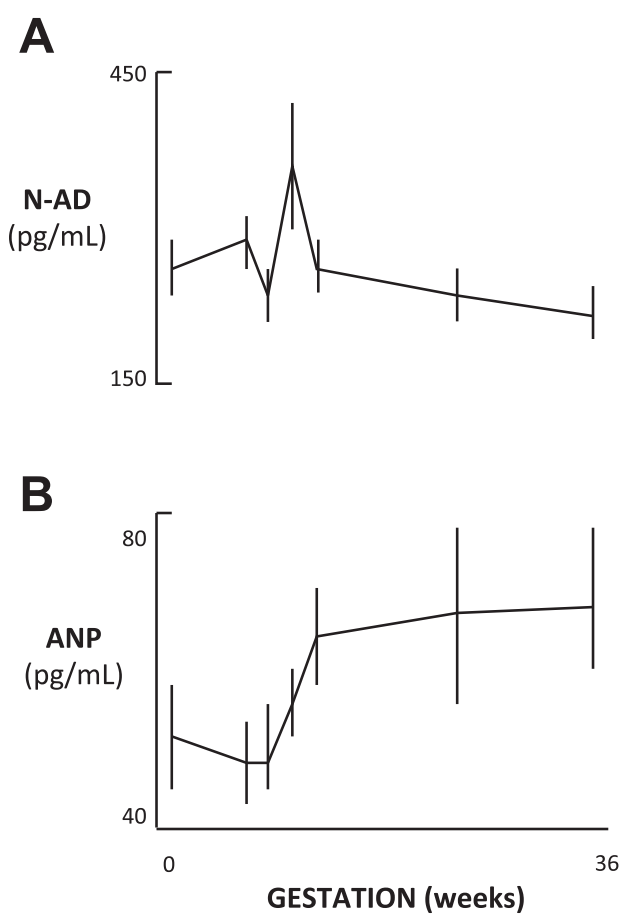

Fig. 8. Changes in plasma noradrenaline $(\mathrm{N}-\mathrm{AD}, \mathrm{pg} / \mathrm{ml})(A)$ and atrial natriuretic peptide (ANP, pg/ml) $(B)$ in human pregnancy. [Redrawn from Chapman et al. (8); Macmillan Publishers Ltd., Kidney International, 54, $2056-$ 2063, 1998]. demand for extra salt and water. The massive increase in sodium retention is partly masked by increased water retention because in pregnancy, the threshold to vasopressin-induced hyperosmotic stimulation is reduced, leading to the characteristic hyponatremic hypervolemia of pregnancy (6).

The profound need for salt in pregnancy and the role of the RAAS system in fulfilling that role is emphasized by studies in the Yanamamo Indians, who at the time of the study lived on a no-salt diet (52). Their daily loss of sodium was about 1 $\mathrm{mEq} / \mathrm{day}$ (assuming a urinary output of about $1 \mathrm{l} / \mathrm{day}$ ), and a measured urinary sodium concentration of $1 \mathrm{mEq} / \mathrm{l}$. When urinary aldosterone levels from pregnant Yanamamo women were compared with their sodium excretion, they were extraordinarily high $(585 \pm 46 \mathrm{ng} / \mathrm{ml})$ compared with nonpregnant $(38.8 \pm 31.4 \mathrm{ng} / \mathrm{ml})$ and lactating pregnant Yanamamo women $(46.2 \pm 62.5 \mathrm{ng} / \mathrm{ml})$, resulting in only a slightly lower sodium excretion (0.7 compared with $1.4 \mathrm{mEq} / \mathrm{l}$ and $0.8 \mathrm{mEq} / \mathrm{l}$, respectively). Presumably, gastrointestinal and sweat losses of sodium were also reduced below nonpregnant levels. Levels of aldosterone were far in excess of pregnant Guyami women who had a high-salt intake (urinary sodium; $77.8 \pm 30 \mathrm{mEq} / \mathrm{l}$ ) and lower urinary aldosterone $(92.1 \pm 119 \mathrm{ng} / \mathrm{ml})(53)$, even though pregnant Guyami women also had higher urinary aldosterone levels and lower urinary sodium levels than nonpregnant tribal women. Like urinary aldosterone, plasma renin activity in pregnant Yanamamo women was very much greater $\left(25.6 \pm 6.4 \mathrm{ng} \cdot \mathrm{ml}^{-1} \cdot \mathrm{h}^{-1}\right)$ compared with lactating and nonpregnant Yanamamo women $(5.0 \pm 2.6$ and $6.2 \pm 4.1$ $\mathrm{ng} \cdot \mathrm{ml}^{-1} \cdot \mathrm{h}^{-1}$, respectively) (53). Thus, in Yanamamo women, one can only assume that much of the increase in renin activity is, in fact, due to very high rates of secretion of renal (i.e., active renin). These data emphasize the interaction between the demand for salt in pregnancy and the activity of the RAAS. This demand for sodium is much greater than that of lactating women from the same tribes, because of the large capacitance of the circulation and the high GFR characteristic of pregnancy but not lactation. After birth, with reversion to a smaller blood volume and lower GFR, the demand for salt is reduced; also, the concentration of sodium in breast milk is low.

Renal function in pregnancy: the intrarenal RAS and the circulating RAAS. GFR used to be described as the "first factor" involved in control of sodium excretion and aldosterone as the "second factor". This was based on the fact that GFR is high (about 170 l/day), so the amount of sodium filtered by the kidney is high (about $24,000 \mathrm{mmol} / \mathrm{day}$ ). Of that amount, $99 \%$ is reabsorbed by the renal tubules. This reabsorptive process accounts for about $90 \%$ of renal oxygen consumption, which increases in proportion to the filtered load (i.e., the amount reabsorbed) (23). Aldosterone can regulate the excretion of up to about $2 \%$ of this filtered sodium load. Progesterone is natriuretic because it is a natural antagonist of aldosterone (51).

The renal tubules also balance the amount of sodium reabsorbed to keep it in proportion to the GFR, a phenomenon known as glomerulotubular balance. Glomerulotubular balance only maintains the fraction of glomerular filtrate reabsorbed constant. Thus, a rise in GFR, such as that occurs in pregnancy would result in an increase in the amount of sodium excreted, unless there was a compensatory increase in aldosterone and ANG II-mediated sodium reabsorption.

ANG II has a multiplicity of actions important for maintaining tissue perfusion. Most of these are mediated via the $\mathrm{AT}_{1} \mathrm{R}$. 
In the 1950s and 1960s, ANG II's role as a key regulator of aldosterone, a salt-retaining hormone, which acts in the distal segments of the nephron, was firmly established. Its role in controlling renal salt reabsorption is, however, not confined to this indirect pathway. The proximal convoluted tubule reabsorbs about $65 \%$ of the filtered sodium load, and blockade of the proximal convoluted tubule ANG II/AT $\mathrm{AT}_{1} \mathrm{R}$ interaction reduces this amount $(13,22)$, demonstrating the key role of the intrarenal RAS described by Navar et al. (47) in sodium homeostasis. ANG II/AT $\mathrm{A}_{1} \mathrm{R}$ interactions also influence the activity of other sodium transporters located along the renal tubule (see Ref. 47).

Pregnancy is a proangiogenic state-role of the RAS. It is likely that there are other actions of the maternal circulating RAAS in pregnancy. One is its role in angiogenesis. Pregnancy is a "proangiogenic state". The increases in renal blood flow, the growth of the uteroplacental circulation, the marked increase in the vascularity of the mammary vascular bed, and possibly changes in vascularity of other tissues, including arterial remodeling mentioned above, may involve the RAS.

In certain tissues, the RAS is clearly involved in angiogenesis, such as in renal development (81) and in the eye (42). Angiotensin is known to induce angiogenesis via an ANG $\mathrm{II} / \mathrm{AT}_{1} \mathrm{R}$ interaction, and we postulate it may be a key factor in placental angiogenesis (58). Angiogenesis is stimulated in human umbilical vein cells by ANG II (24). In early pregnancy, VEGF levels are increased in parallel with the increase in $\beta$-hCG levels (18). $\beta$-hCG also stimulates prorenin secretion by the ovary (27) and by placental trophoblast (17). Because the $(\mathrm{P}) \mathrm{RR}$ is associated with increased VEGF levels in the eye and this effect is abolished by (P)RR blockade and by blockade of ERK1/2 signaling (87), it is tempting to suggest that the (P)RR-prorenin/renin system, which is activated in early pregnancy by hCG could be involved in this early high level of production of VEGF and, hence, in stimulation of angiogenesis. Also, aldosterone has been shown in vitro to stimulate VEGF production (85). So the rapid onset of increased tissue perfusion of the uterus, breasts, skin, and kidney, which must involve increased vascularity, may, in part, be determined by the early activation of the RAAS.

\section{Perspectives and Significance}

The activity of the circulating RAAS in pregnancy is influenced by contributions from tissue RASs (in particular, the ovary), as well as the secretion of active renin by the kidney. Angiotensinogen also plays a major role. Since its production is strongly influenced by estrogens, it would seem that maintenance of fluid and electrolyte homeostasis in normal pregnancy is assured. Even so, when dietary salt intake is limited, the circulating RAAS is activated further through secretion of active renin.

Although the renin-angiotensin system is usually thought of as "hypertensinogenic" in normal pregnancy, the balance between the production of the vasodilator ANG peptide (ANG 1-7) and the vasoconstrictor peptide, ANG II, is altered so that the vasopressor actions of the circulating RAAS are, to some extent, offset (Fig. 3). Furthermore, under the influence of estrogens, the vasodilator $\mathrm{AT}_{2} \mathrm{R}$ is induced. As described above, this receptor has been shown to be important within the uteroplacental vasculature in maintaining uteroplacental blood flow. Thus, through changing activity of the various components of the circulating RAAS and its receptors, the obligatory activation of the RAAS in pregnancy, which, in terms of human evolution, has been critical for maintenance of salt and water balance, does not cause hypertension.

Despite the fact that AGT levels are linked to estrogen production, overall, the activity of the circulating RAAS in pregnancy is driven mainly by maternal physiological demand, so it is not surprising that its activity does not reflect the role(s) of placental and possibly other intrauterine RASs in pathological pregnancies, e.g., intrauterine growth restriction or preeclampsia.

\section{REFERENCES}

1. Abduljalil K, Furness P, Johnson TN, Rostami-Hodjegan A, Soltani H. Anatomical, physiological and metabolic changes with gestational age during normal pregnancy: a database for parameters required in physiologically based pharmacokinetic modelling. Clin Pharmacokinet 51: 365396, 2012.

2. Albiston AL, Fernando R, Ye S, Peck GR, Chai SY. Alzheimer's, angiotensin IV and an aminopeptidase. Biol Pharm Bull 27: 765-767, 2004.

3. Albiston AL, McDowall SG, Matsacos D, Sim P, Clune E, Mustafa T, Lee J, Mendelsohn FA, Simpson RJ, Connolly LM, Chai SY. Evidence that the angiotensin IV (AT(4)) receptor is the enzyme insulin-regulated aminopeptidase. J Biol Chem 276: 48623-48626, 2001.

4. Baker PN, Broughton Pipkin F, Symonds EM. Platelet angiotensin II binding and plasma renin concentration, plasma renin substrate and plasma angiotensin II in human pregnancy. Clin Sci (Lond) 79: 403-408, 1990.

5. Brosnihan KB, Neves LA, Anton L, Joyner J, Valdes G, Merrill DC. Enhanced expression of Ang-(1-7) during pregnancy. Braz J Med Biol Res 37: 1255-1262, 2004.

6. Brunton PJ, Arunachalam S, Russel JA. Control of neurohypophysial hormone secretion, blood osmolality and volume in pregnancy. J Physiol Pharmacol 59 Suppl 8: 27-45, 2008.

7. Burrell JH, Lumbers ER. Angiotensin receptor subtypes in the uterine artery during ovine pregnancy. Eur J Pharmacol 330: 257-267, 1997.

8. Chapman AB, Abraham WT, Zamudio S, Coffin C, Merouani A, Young D, Johnson A, Osorio F, Goldberg C, Moore LG, Dahms T, Schrier RW. Temporal relationships between hormonal and hemodynamic changes in early human pregnancy. Kidney Int 54: 2056-2063, 1998.

9. Chapman AB, Zamudio S, Woodmansee W, Merouani A, Osorio F, Johnson A, Moore LG, Dahms T, Coffin C, Abraham WT, Schrier RW. Systemic and renal hemodynamic changes in the luteal phase of the menstrual cycle mimic early pregnancy. Am J Physiol Renal Physiol 273: F777-F782, 1997.

10. Coleman JK, Krebs LT, Hamilton TA, Ong B, Lawrence KA, Sardinia MF, Harding JW, Wright JW. Autoradiographic identification of kidney angiotensin IV binding sites and angiotensin IV-induced renal cortical blood flow changes in rats. Peptides 19: 269-277, 1998.

11. Conrad KP. Maternal vasodilation in pregnancy: the emerging role of relaxin. Am J Physiol Regul Integr Comp Physiol 301: R267-R275, 2011.

12. Conrad KP, Novak J. Emerging role of relaxin in renal and cardiovascular function. Am J Physiol Regul Integr Comp Physiol 287: R250-R261, 2004.

13. Crowley SD, Zhang J, Herrera M, Griffiths R, Ruiz P, Coffman TM. Role of $\mathrm{AT}_{1}$ receptor-mediated salt retention in angiotensin II-dependent hypertension. Am J Physiol Renal Physiol 301: F1124-F1130, 2011.

14. Danielson LA, Sherwood OD, Conrad KP. Relaxin is a potent renal vasodilator in conscious rats. J Clin Invest 103: 525-533, 1999.

15. de Gasparo M, Catt KJ, Inagami T, Wright JW, Unger T. International union of pharmacology. XXIII. The Angiotensin II Receptors. Pharmacol Rev 52: 415-472, 2000.

16. Derkx FH, Alberda AT, de Jong FH, Zeilmaker FH, Makovitz JW, Schalekamp MA. Source of plasma prorenin in early and late pregnancy: observations in a patient with primary ovarian failure. J Clin Endocrinol Metab 65: 349-354, 1987. 
17. Downing GJ, Maulik D, Poisner AM. Human chorionic gonadotropin stimulates placental prorenin secretion: evidence for autocrine/paracrine regulation. J Clin Endocrinol Metab 81: 1027-1030, 1996.

18. Evans P, Wheeler T, Anthony F, Osmond C. Maternal serum vascular endothelial growth factor during early pregnancy. Clin Sci 92: 567-571, 1997.

19. Gant NF, Daley GL, Chand S, Whalley PJ, MacDonald PC. A study of angiotensin II pressor response throughout primigravid pregnancy. J Clin Invest 52: 2682-2689, 1973.

20. Gordon DB, Sachin IN. Chromatographic separation of multiple renin substrates in women: effect of pregnancy and oral contraceptives. Proc Soc Exp Biol Med 156: 461-464, 1977.

21. Gray MJ, Plentl AA. The variations of the sodium space and the total exchangeable sodium during pregnancy. J Clin Invest 33: 347-353, 1954.

22. Gurley SB, Riquier-Brison AD, Schnermann J, Sparks MA, Allen AM, Haase VH, Snouwaert JN, Le TH, McDonough AA, Koller BH, Coffman TM. $\mathrm{AT}_{1} \mathrm{~A}$ angiotensin receptors in the renal proximal tubule regulate blood pressure. Cell Metab 13: 469-475, 2011.

23. Heinz V. Renal hemodynamic and oxygen consumption. In: Renal Function: Mechanisms Preserving Fluid and Solute Balance in Health. Boston, MA: Little Brown, 1983, p. 101-118.

24. Herr D, Rodewald M, Fraser HM, Hack G, Konrad R, Kreienberg R, Wulff C. Regulation of endothelial proliferation by the renin-angiotensin system in human umbilical vein endothelial cells. Reproduction 136: 125-130, 2008.

25. Immonen I, Siimes A, Stenman UH, Karkkainen J, Fyhrquist F. Plasma renin substrate and oestrogens in normal pregnancy. Scand J Clin Lab Invest 43: 61-65, 1983.

26. Irons DW, Baylis PH, Davison JM. The metabolic clearance of atrial natriuretic peptide during human pregnancy. Am J Obstet Gynecol 175: 449-454, 1996.

27. Itskovitz J, Sealey JE, Glorioso N, Rosenwaks Z. Plasma prorenin response to human chorionic gonadotropin in ovarian-hyperstimulated women: correlation with the number of ovarian follicles and steroid hormone concentrations. Proc Natl Acad Sci USA 84: 7285-7289, 1987.

28. Joyner J, Neves LA, Granger JP, Alexander BT, Merrill DC, Chappell MC, Ferrario CM, Davis WP, Brosnihan KB. Temporal-spatial expression of ANG-(1-7) and angiotensin-converting enzyme 2 in the kidney of normal and hypertensive pregnant rats. Am J Physiol Regul Integr Comp Physiol 293: R169-R177, 2007.

29. Joyner J, Neves LA, Stovall K, Ferrario CM, Brosnihan KB. Angiotensin-(1-7) serves as an aquaretic by increasing water intake and diuresis in association with downregulation of aquaporin-1 during pregnancy in rats. Am J Physiol Regul Integr Comp Physiol 294: R1073-R1080, 2008.

30. Kemp BA, Bell JF, Rottkamp DM, Howell NL, Shao W, Navar LG, Padia SH, Carey RM. Intrarenal angiotensin III is the predominant agonist for proximal tubule angiotensin type 2 receptors. Hypertension 60 : 387-395, 2012.

31. Lew RA, Warner FJ, Hanchapola I, Yarski MA, Manohar J, Burrell LM, Smith AI. Angiotensin-converting enzyme 2 catalytic activity in human plasma is masked by an endogenous inhibitor. Exp Physiol 93: 685-693, 2008.

32. Lumbers ER. Activation of renin in human amniotic fluid by low $\mathrm{pH}$. Enzymologia 40: 329-336, 1971.

33. Lumbers ER. Functions of the renin-angiotensin system during development. Clin Exp Pharmacol Physiol 22: 499-505, 1995.

34. Lumbers ER. The ovary. In: The Renin-Angiotensin System, vol. 1, edited by Robertson JIS and Nichol GM, New York: C. V. Mosby, p. 46.4146.12, 1993.

35. Lumbers ER. Peripheral vascular reactivity to angiotensin and noradrenaline in pregnant and non-pregnant women. Aust J Exp Biol Med Sci 48: 493-500, 1970.

36. Lumbers ER, McCloskey DI, Potter EK. Inhibition by angiotensin II of baroreceptor-evoked activity in cardiac vagal efferent nerves in the dog. $J$ Physiol 294: 69-80, 1979.

37. Magaldi AJ, Cesar KR, de Araujo M, Simoes e Silva AC, Santos RA. Angiotensin-(1-7) stimulates water transport in rat inner medullary collecting duct: evidence for involvement of vasopressin V2 receptors. Pflügers Arch 447: 223-230, 2003.

38. Matsukawa T, Miyamoto T. Angiotensin II-stimulated secretion of arginine vasopressin is inhibited by atrial natriuretic peptide in humans. Am J Physiol Regul Integr Comp Physiol 300: R624-R629, 2011.
39. McKinley MJ, Cairns MJ, Denton DA, Egan G, Mathai ML, Uschakov A, Wade JD, Weisinger RS, Oldfield BJ. Physiological and pathophysiological influences on thirst. Physiol Behav 81: 795-803, 2004.

40. McMullen JR, Gibson KJ, Lumbers ER, Burrell JH. Selective downregulation of $\mathrm{AT}_{2}$ receptors in uterine arteries from pregnant ewes given 24-h intravenous infusions of angiotensin II. Regul Pept 99: 119-129, 2001.

41. McMullen JR, Gibson KJ, Lumbers ER, Burrell JH, Wu J. Interactions between $\mathrm{AT}_{1}$ and $\mathrm{AT}_{2}$ receptors in uterine arteries from pregnant ewes. Eur J Pharmacol 378: 195-202, 1999.

42. Moravski CJ, Kelly DJ, Cooper ME, Gilbert RE, Bertram JF, Shahinfar S, Skinner SL, Wilkinson-Berka JL. Retinal neovascularization is prevented by blockade of the renin-angiotensin system. Hypertension 36: $1099-1104,2000$.

43. Morris BJ. Activation of human inactive ("pro-") renin by cathepsin D and pepsin. J Clin Endocrinol Metab 46: 153-157, 1978.

44. Morris BJ, Lumbers ER. The activation of renin in human amniotic fluid by proteolytic enzymes. Biochim Biophys Acta 289: 385-391, 1972.

45. Mustafa T, Chai SY, May CN, Mendelsohn FA, Albiston AL. Oxytocinase/insulin-regulated aminopeptidase is distributed throughout the sheep, female reproductive tract and is regulated by oestrogen in the uterus. Regul Pept 122: 85-89, 2004.

46. Naden RP, Rosenfeld CR. Effect of angiotensin II on uterine and systemic vasculature in pregnant sheep. J Clin Invest 68: 468-474, 1981.

47. Navar LG, Kobori H, Prieto MC, Gonzalez-Villalobos RA. Intratubular renin-angiotensin system in hypertension. Hypertension 57: 355-362, 2011.

48. Nguyen G. Renin, (pro)renin and receptor: an update. Clin Sci 120: 169-178, 2011.

49. Nguyen G, Delarue F, Burckle C, Bouzhir L, Giller T, Sraer JD. Pivotal role of the renin/prorenin receptor in angiotensin II production and cellular responses to renin. J Clin Invest 109: 1417-1427, 2002.

50. Novak J, Danielson LA, Kerchner LJ, Sherwood OD, Ramirez RJ, Moalli PA, Conrad KP. Relaxin is essential for renal vasodilation during pregnancy in conscious rats. J Clin Invest 107: 1469-1475, 2001.

51. Oelkers W. Antimineralocorticoid activity of a novel oral contraceptive containing drospirenone, a unique progestogen resembling natural progesterone. Eur J Contracep Reprod Health Care 7 Suppl 3: 19-26; discussion $42-13,2002$.

52. Oliver WJ, Cohen EL, Neel JV. Blood pressure, sodium intake, and sodium related hormones in the Yanomamo Indians, a "no-salt" culture. Circulation 52: 146-151, 1975.

53. Oliver WJ, Neel JV, Grekin RJ, Cohen EL. Hormonal adaptation to the stresses imposed upon sodium balance by pregnancy and lactation in the Yanomama Indians, a culture without salt. Circulation 63: 110-116, 1981.

54. Overgaard MT, Oxvig C, Christiansen M, Lawrence JB, Conover CA, Gleich GJ, Sottrup-Jensen L, Haaning J. Messenger ribonucleic acid levels of pregnancy-associated plasma protein-A and the proform of eosinophil major basic protein: expression in human reproductive and nonreproductive tissues. Biol Reprod 61: 1083-1089, 1999.

55. Oxvig C, Haaning J, Kristensen L, Wagner JM, Rubin I, Stigbrand T, Gleich GJ, Sottrup-Jensen L. Identification of angiotensinogen and complement $\mathrm{C} 3 \mathrm{dg}$ as novel proteins binding the proform of eosinophil major basic protein in human pregnancy serum and plasma. J Biol Chem 270: 13645-13651, 1995.

56. Parente JV, Franco JG Jr, Greene LJ, Meirelles RS, Martinez AR. Angiotensin-converting enzyme: serum levels during normal pregnancy. Am J Obstet Gynecol 135: 586-589, 1979.

57. Pawlak MA, Macdonald GJ. Altered number of platelet angiotensin II receptors in relation to plasma agonist concentrations in normal and hypertensive pregnancy. J Hypertens 10: 813-819, 1992.

58. Pringle KG, Lumbers ER. The placental renin angiotensin system. In: Placenta: Functions, Development and Disease. Hauppauge, NY: Nova Publishers, In press, 2013.

59. Pringle KG, Tadros MA, Callister RJ, Lumbers ER. The expression and localization of the human placental prorenin/renin-angiotensin system throughout pregnancy: roles in trophoblast invasion and angiogenesis? Placenta 32: 956-962, 2011.

60. Ramchandra R, Yao ST, May CN. Organ selective regulation of sympathetic outflow by the brain angiotensin system. Curr Hypertens Rep 15: 401-408, 2013.

61. Rizk DE. A study of alpha-human atrial natriuretic peptide in normal pregnancy and in pre-eclampsia. J Obstet Gynaecol 17: 234-238, 1997. 
62. Sampson AK, Hilliard LM, Moritz KM, Thomas MC, Tikellis C, Widdop RE, Denton KM. The arterial depressor response to chronic low-dose angiotensin II infusion in female rats is estrogen dependent. Am J Physiol Regul Integr Comp Physiol 302: R159-R165, 2012.

63. Sampson AK, Moritz KM, Jones ES, Flower RL, Widdop RE, Denton KM. Enhanced angiotensin II type 2 receptor mechanisms mediate decreases in arterial pressure attributable to chronic low-dose angiotensin II in female rats. Hypertension 52: 666-671, 2008.

64. Santos RA, Ferreira AJ, Verano-Braga T, Bader M. Angiotensinconverting enzyme 2, Angiotensin-(1-7) and Mas: new players of the renin angiotensin system. J Endocrinol 216: R1-R17, 2013.

65. Santos RA, Simoes e Silva AC, Maric C, Silva DM, Machado RP, de Buhr I, Heringer-Walther S, Pinheiro SV, Lopes MT, Bader M, Mendes EP, Lemos VS, Campagnole-Santos MJ, Schultheiss HP, Speth R, Walther T. Angiotensin-(1-7) is an endogenous ligand for the G protein-coupled receptor Mas. Proc Natl Acad Sci USA 100: $8258-$ 8263, 2003.

66. Saris JJ, 't Hoen PA, Garrelds IM, Dekkers DH, den Dunnen JT, Lamers JM, Jan Danser AH. Prorenin induces intracellular signaling in cardiomyocytes independently of angiotensin II. Hypertension 48: $564-$ 571, 2006.

67. Schalekamp MA, Derkx FH, Deinum J, Danser AJ. Newly developed renin and prorenin assays and the clinical evaluation of renin inhibitors. $J$ Hypertens 26: 928-937, 2008.

68. Sealey JE, Atlas SA, Glorioso N, Manapat H, Laragh JH. Cyclical secretion of prorenin during the menstrual cycle: synchronization with luteinizing hormone and progesterone. Proc Natl Acad Sci USA 82: 8705-8709, 1985.

69. Skinner SL. The renin system in fertility and normal human pregnancy. In: The Renin-Angiotensin System, vol. 1, edited by Robertson JIS and Nichol GM. New York: C. V. Mosby, 1993, p. 50.51-46.16.

70. Skinner SL, Lumbers ER, Symonds EM. Analysis of changes in the renin-angiotensin system during pregnancy. Clin Sci 42: 479-488, 1972.

71. Smith MC, Danielson LA, Conrad KP, Davison JM. Influence of recombinant human relaxin on renal hemodynamics in healthy volunteers. J Am Soc Nephrol 17: 3192-3197, 2006.

72. Spat A, Hunyady L. Control of aldosterone secretion: a model for convergence in cellular signaling pathways. Physiol Rev 84: 489-539, 2004.

73. Stennett AK, Qiao X, Falone AE, Koledova VV, Khalil RA. Increased vascular angiotensin type 2 receptor expression and NOS-mediated mechanisms of vascular relaxation in pregnant rats. Am J Physiol Heart Circ Physiol 296: H745-H755, 2009.

74. Stevens AD, Lumbers ER. The effects of long-term infusions of angiotensin II into the pregnant ewe on uterine blood flow and on the fetus. $J$ Cardiovasc Pharmacol 34: 824-830, 1999.

75. Sykes SDPK, Zhou A, Dekker GA, Roberts CT, Lumbers ER. The balance between human maternal plasma angiotensin II and 1 angiotensin
1-7 levels in early gestation pregnancy is influenced by fetal sex. $J$ Renin-Angiotensin Aldosterone Syst In press.

76. Sykes SD, Pringle KG, Zhou A, Dekker GA, Roberts CT, Lumbers ER. Fetal sex and the circulating renin-angiotensin system during early gestation in women who later develop preeclampsia or gestational hypertension. J Human Hypertens 2013 Jun 20. doi:10.1038/jhh.2013.51. [Epub ahead of print].

77. Takeda-Matsubara Y, Iwai M, Cui TX, Shiuchi T, Liu HW, Okumura M, Ito M, Horiuchi M. Roles of angiotensin type 1 and 2 receptors in pregnancy-associated blood pressure change. Am J Hypertens 17: 684$689,2004$.

78. Tewksbury DA. Quantitation of five forms of high molecular weight angiotensinogen from human placenta. Am J Hypertens 9: 1029-1034, 1996.

79. Tewksbury DA, Dart RA. High molecular weight angiotensinogen levels in hypertensive pregnant women. Hypertension 4: 729-734, 1982.

80. Tewksbury DA, Kaiser SJ, Burrill RE. A study of the temporal relationship between plasma high molecular weight angiotensinogen and the development of pregnancy-induced hypertension. Am J Hypertens 14: 794-797, 2001.

81. Tufro-McReddie A, Romano LM, Harris JM, Ferder L, Gomez RA. Angiotensin II regulates nephrogenesis and renal vascular development. Am J Physiol Renal Fluid Electrolyte Physiol 269: F110-F115, 1995.

82. Valdes G, Corthorn J. Challenges posed to the maternal circulation by pregnancy. Integr Blood Press Control 4: 45-53, 2011.

83. Valdes G, Kaufmann P, Corthorn J, Erices R, Brosnihan KB, JoynerGrantham J. Vasodilator factors in the systemic and local adaptations to pregnancy. Reprod Biol Endocrinol 7: 79, 2009.

84. van Dijk DJ, Boner G, Giler S, Erman A. Increased serum angiotensinconverting enzyme activity and plasma angiotensin II levels during pregnancy and postpartum in the diabetic rat. J Renin Angiotensin Aldosterone Syst 2: 193-198, 2001.

85. Walczak C, Gaignier F, Gilet A, Zou F, Thornton SN, Ropars A. Aldosterone increases VEGF-A production in human neutrophils through PI3K, ERK1/2 and p38 pathways. Biochim Biophys Acta 1813: 2125 2132, 2011.

86. Weyer K, Glerup S. Placental regulation of peptide hormone and growth factor activity by proMBP. Biol Reprod 84: 1077-1086, 2011.

87. Wilkinson-Berka JL, Heine R, Tan G, Cooper ME, Hatzopoulos KM, Fletcher EL, Binger KJ, Campbell DJ, Miller AG. RILLKKMPSV influences the vasculature, neurons and glia, and (pro)renin receptor expression in the retina. Hypertension 55: 1454-1460, 2010.

88. Yang R, Walther T, Gembardt F, Smolders I, Vanderheyden P, Albiston AL, Chai SY, Dupont AG. Renal vasoconstrictor and pressor responses to angiotensin IV in mice are AT1a-receptor mediated. $J$ Hypertens 28: 487-494, 2010

89. Zhou A, Carrell RW, Murphy MP, Wei Z, Yan Y, Stanley PL, Stein PE, Broughton Pipkin F, Read RJ. A redox switch in angiotensinogen modulates angiotensin release. Nature 468: 108-111, 2010. 